\title{
Implementation of MPPT Algorithm and Supervision of Shading on Photovoltaic Module
}

\author{
Samia Latreche \\ Automatic Laboratory, Electrical \\ Engineering Department, \\ Ferhat Abbas Setif University 1, \\ (UFAS1), Setif, Algeria \\ ksamia2002@yahoo.fr
}

\author{
Abd Essalam Badoud \\ Automatic Laboratory, Electrical \\ Engineering Department, \\ Ferhat Abbas Setif University 1, \\ (UFAS1), Setif, Algeria \\ badoudabde@yahoo.fr
}

\author{
Mabrouk Khemliche \\ Automatic Laboratory, Electrical \\ Engineering Department, \\ Ferhat Abbas Setif University 1, \\ (UFAS1), Setif, Algeria \\ mabroukkhemliche@univ-setif.dz
}

\begin{abstract}
This paper presents an implementation of MPPT (maximum power point tracking) algorithm based on real-time measurements and on model-based simulation. For the supervision of a photovoltaic module, different cases of shading are used. Attention was given on advanced control for the supervision of a photovoltaic system according to the need to maximize energy output. Experimental results verified the performance and the feasibility of the proposed system.
\end{abstract}

Keywords-implementation; simulation; supervision; MPPT algorithm; photovoltaic; shading

\section{INTRODUCTION}

Fossil fuel energy causes a lot of concerns, from global warming and air pollution, to the issue of their limited reserves [1]. Solar energy is a green and renewable energy source. It has been widely exploited in grid-connected systems, in PV pumps and in stand-alone systems. In most systems PV modules are required to be connected in series to form PV panels. PV applications can be classified into two broad categories: the stand-alone and the grid-connected systems. A stand-alone system is widely used in remote places where access to electricity is not viable. The stand-alone configuration can provide well regulated load voltage but the reliability of power supply cannot be guaranteed. This enables the overall PV panel to obtain high input voltage producing high output power to justify the use of MPPT control [2]. Increasing the efficiency of solar cell is an open issue. Different kinds of solar cells have been designed and introduced. The solar panel, the most essential part of a photovoltaic system, converts solar to electrical energy, having nonlinear I/V characteristic curves. Modeling of photovoltaic system predicts the system's electrical behavior in various environmental and load conditions. A PV generation system should operate at its maximum power point (MPP) to increase system efficiency [3]. Therefore, MPP tracking is very crucial for PV power generation systems, their optimum use is to operate at MPP as much as possible. Since the earliest MPPT methods published in 1960s, we can count over than fifteen MPPT methods [4, 5]. They can be classified according to the research process of MPP into direct and indirect methods [6]. Indirect methods, like short circuit and open circuit methods need a prior evaluation of the PV panel. They are based on mathematical relationships which are not valid for all operating meteorological conditions. So, they cannot obtain exactly the maximum power of PV module at any irradiance and cell temperature. Direct methods operate at every meteorological condition. The most used methods are perturb and observe (P\&O), incremental conductance (INC) [7], and fuzzy logic (FL) based MPPT. Some direct MPPT methods can be classified according to the variable being tracked. MPPT algorithms with fixed step and with variable step can be differentiated. Classifications can be built based on implementation simplicity, energy efficiency, convergence speed, sensors required and cost effectiveness. These criteria are often dependent to each other, and make the choice of MPPT method more difficult [8-10].

\section{PROPOSED METHOD}

The proposed scheme of the controller is shown in Figure 1. It is composed of an array of photovoltaic modules $(s \times p)$ composed of s cells in series connection and $p$ cells in parallel connection, depending on the power system. The buck-boost DC/DC converters use MPPT for the PV array in order to extract the maximum available power from them. Lead-acid battery is used to store the energy, to regulate the DC-bus voltage through a reversible current DC/DC converter and to supply the motor pump at the low solar irradiance conditions.

\section{ANALYSIS OF THE PV SYSTEM}

The solar cell is the basic unit of the PV modules which converts photons directly into electrical energy. A solar cell is generally represented by a circuit diagram [11] as shown in Figure 2. The one diode model is commonly used for modeling cells of crystalline silicon technology. The equivalent electric circuit comprises a current source, two resistors, and a singlediode. The one-diode model contains five parameters which describe the PV cell properties. The voltage current relationship that can be deduced using the equivalent circuit results in a transcendental equation [12]. The modeling of the PV power supply system is the initial stage that must precede all sizing simulation applications. PV system's modeling is quite complex. Several models are proposed for modeling the different components of a stand-alone PV system [13]. These 
are based on analytical models or numerical simulations. Other methods are based on software simulations using [14, 15]. Automatic data acquisition systems are currently used for both monitoring the system performance and control of its operation. The obtained information can be used to evaluate the plant efficiency during long periods and to optimize future systems in terms of performance and reliability. These systems are based on the use of microcontroller and microprocessor for PV applications [16].

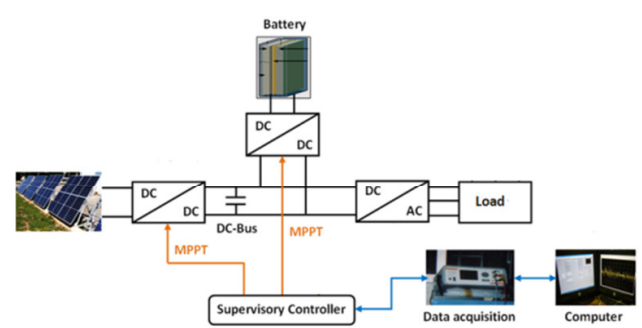

Fig. 1. Photovoltaic system

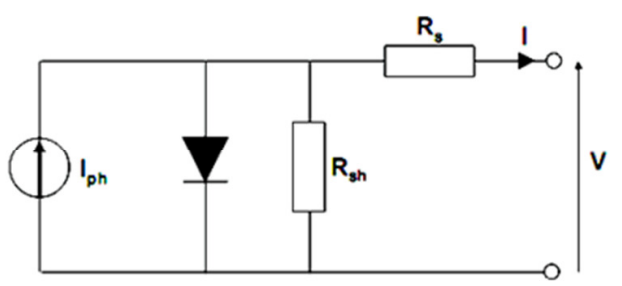

Fig. 2. Equivalent electrical circuit of photovoltaic cell

\section{MPPT CONTROL}

PV modules are known to be nonlinear, and there is one operation point where the PV string generates maximum power. One of the problems in the PV systems is that the amount of electric power by the PV arrays is always changing along with the weather conditions. An MPPT control strategy, which has quickly response characteristics and is able to make good use of the electric power generated in any weather, is needed to solve this problem. The most commonly used MPPT algorithm is the $\mathrm{P} \& \mathrm{O}$, due to its ease of implementation in its basic form [17]: We assume that the PV module operates at a given point, which is outside the MPP, it is perturbed by $\Delta V=V(n)-V(n-1)$, and the change in the power $\Delta P=P(n)-P(n-1)$ is measured. If $\Delta \mathrm{P}>0$, the operation point has approached MPP, and the next perturbation must take place in the same direction as the previous one. If $\Delta \mathrm{P}<0$, the system has moved away from the MPP and, consequently, the next perturbation must be performed in the opposite direction.

\section{VALIDATION OF THE ALGORITHM}

The proposed algorithm was validated by Simulink in two different situations (Figure 3), assuming the presence of the proposed control system and its absence. In both cases the module output power was evaluated in order to perform a subsequent comparison. During the tests, the PV module was submitted to constant temperature and solar irradiance conditions. During the test, a DC/DC converter was connected between the module and the load without controller. In this case the PV module was connected to the generic impedance. Under these conditions, the output power is always less than $800 \mathrm{~W}$, as can be seen in Figure 4. In the latter test the same conditions were maintained, but the MPPT control was properly inserted. In this case the output power is always greater than $850 \mathrm{~W}$ as can be seen in Figure 5 .

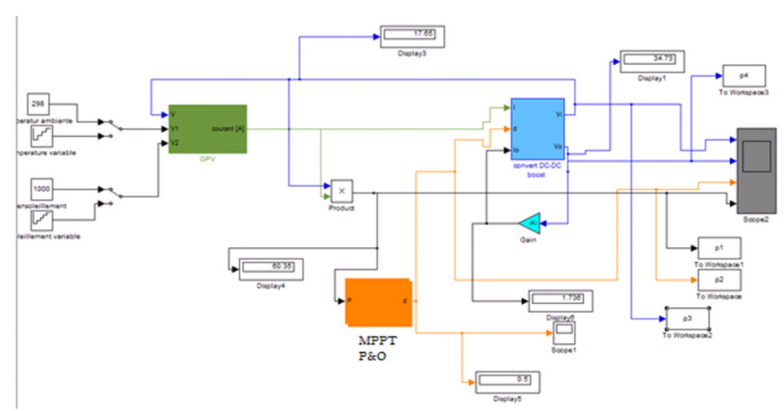

Fig. 3. Simulink model for perturbation and observation MPPT

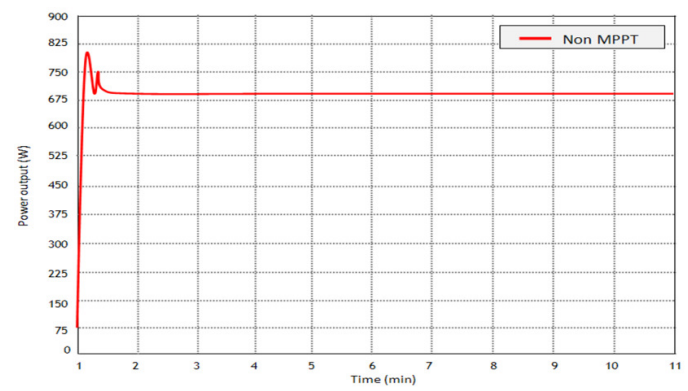

Fig. 4. Output power without MPPT

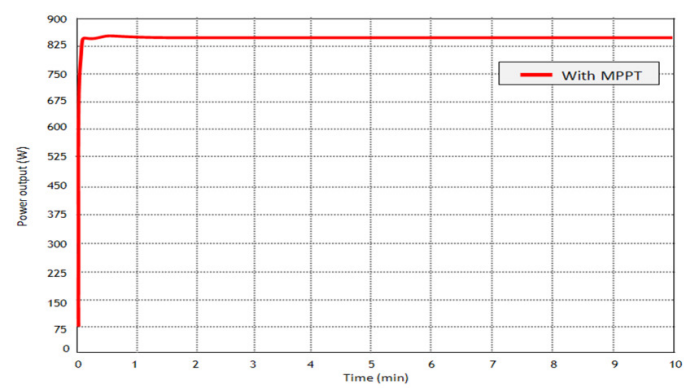

Fig. 5. Output power with MPPT

\section{IMPLEMENTATION OF THE MPPT ALGORITHM}

Figure 6 describes the electrical circuit implemented in Proteus software. The PV array was simulated with two solar energy cases A and B (details in Table I).

TABLE I. SIMULATION DATASHEET

\begin{tabular}{|c|c|c|c|c|}
\hline Cases & $\begin{array}{c}\text { Solar irradiance } \\
\left(\mathbf{m W} / \mathbf{c m}^{2}\right)\end{array}$ & $\begin{array}{c}\text { MPP } \\
\text { Power (W) }\end{array}$ & $\begin{array}{c}\text { MPP } \\
\text { Voltage (V) }\end{array}$ & $\begin{array}{c}\text { MPP } \\
\text { Current (A) }\end{array}$ \\
\hline A & 65.357 & 102.648 & 27.315 & 7.750 \\
\hline B & 24.982 & 42.610 & 32.280 & 2.640 \\
\hline
\end{tabular}




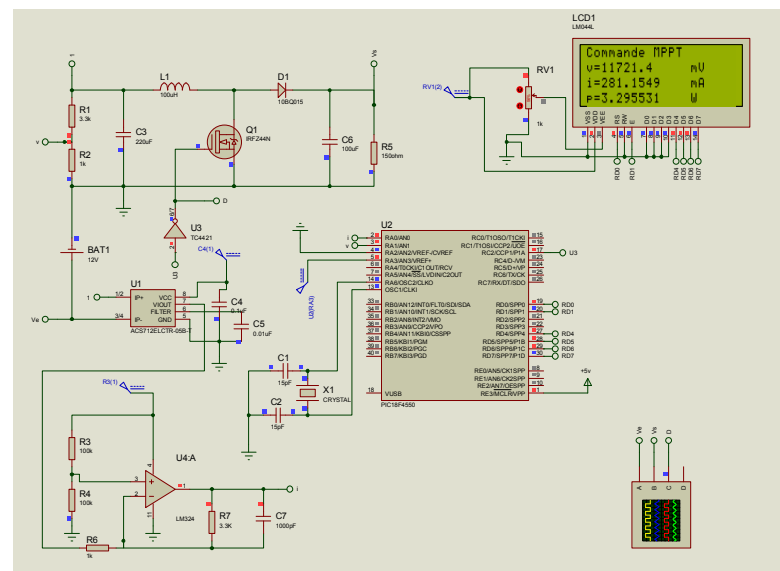

Fig. 6. Electrical scheme in Proteus

Figures 7 and 8 represent respectively I/V and P/V curves under two different cases at $65^{\circ} \mathrm{C}$. The $\mathrm{PV}$ array gives $150 \mathrm{~W}$ maximum power, $43.5 \mathrm{~V}$ open-circuit voltage and $4.75 \mathrm{~A}$ closecircuit current at $1 \mathrm{~kW} / \mathrm{m}^{2}$ solar energy under $25^{\circ} \mathrm{C}$. Solar energy is changed from A to B. However, this part is needed to run only when the environmental conditions are changing. It can be executed with low sampling rate.

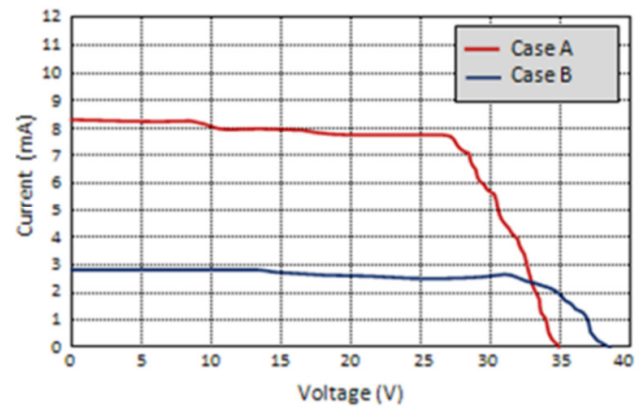

Fig. 7. The $\mathrm{I} / \mathrm{V}$ curve under the cases $\mathrm{A}$ and $\mathrm{B}$ at $65^{\circ} \mathrm{C}$

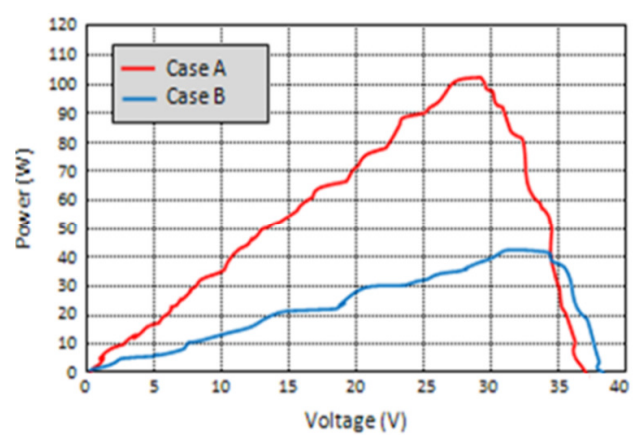

Fig. 8. The $\mathrm{P} / \mathrm{V}$ curve under the cases $\mathrm{A}$ and $\mathrm{B}$ at $65^{\circ} \mathrm{C}$

\section{SUPERVISION OF PV MODULE SHADING}

The model of the complex system is reduced without requiring much computational resources and is suitable for operating in real-time, in order to verify the effectiveness of the system developed under various partial shadow conditions (Figure 9).
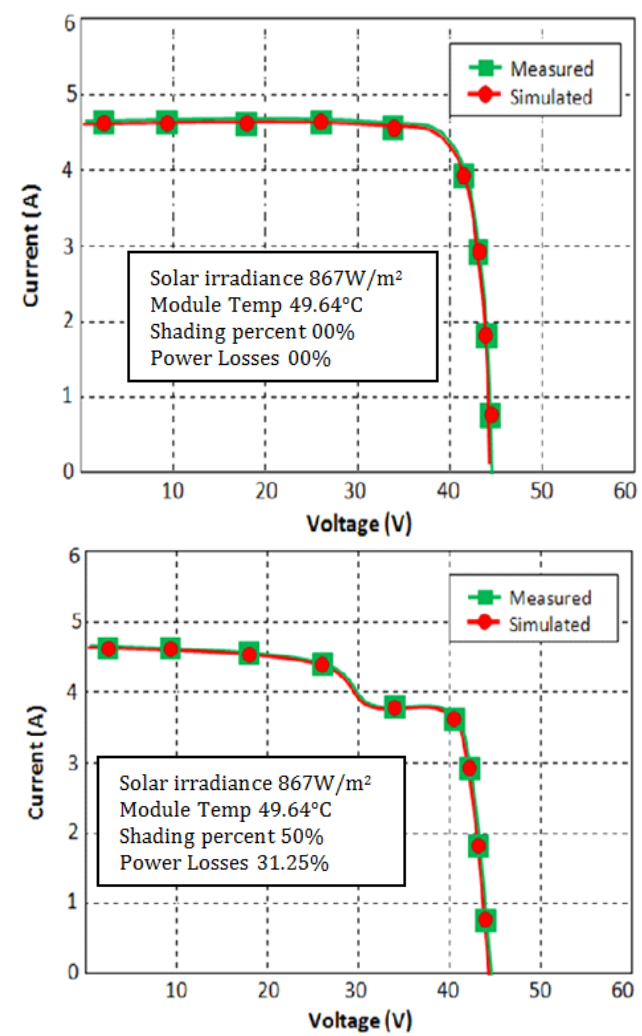

(b) With one cell partially shadowed

(c) Two cells with the same area shadowed
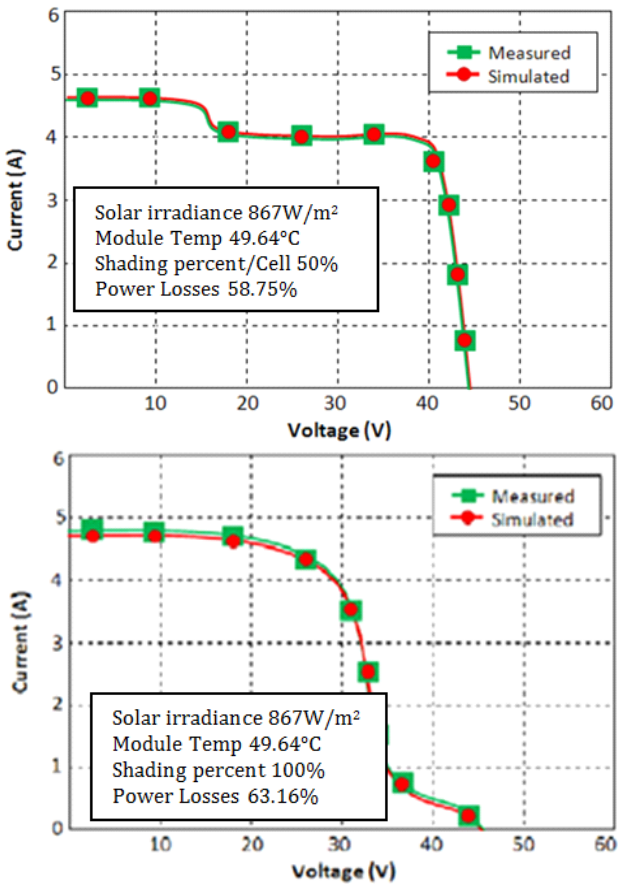

Fig. 9. Measured and simulated I/V characteristics of the PV module

\section{CONCLUSIONS}

Due to the age of the module used, its behavior is not identical to the datasheet. The environmental conditions for the simulation have been adjusted in order to create the same shortcircuit current and open-circuit voltage to the measurement. 
The PV module gives $150 \mathrm{~W}$ maximum power, $43.5 \mathrm{~V}$ opencircuit voltage and $4.75 \mathrm{~A}$ short-circuit current at $1 \mathrm{~kW} / \mathrm{m}^{2}$ solar energy under $25^{\circ} \mathrm{C}$.

An advanced control of the photovoltaic system, in normal or in shadow weather conditions has been realized. Experimental and simulation results were compared in order to confirm the established MPPT control. Experimental measurements of voltage and PV power of MPPT method were conducted under step changing irradiance. The obtained experimental curves are identical to the simulation ones. All results have been achieved while modeling all systems in Simulink and writing all models in Matlab code. The studied schemes include the PV plant model, the estimator parameters, the reference model block and the supervision system control. The block MPPT is necessary to track the maximum power point and to establish the reference voltage in input. It is based on the P\&O algorithm, which step by step researches the point where the first order derivative is zero. The experimental results are quite satisfactory, showing the effectiveness of the proposed control in improving the power quality and the reliability of the power supply.

\section{ACKNOWLEDGMENT}

Authors gratefully thank the University Ferhat Abbas of Sétif (UFAS) for the financial support of this study.

\section{REFERENCES}

[1] M. Dimitropoulou, D. Pylarinos, K. Siderakis, E. Thalassinakis, M. Danikas, "Comparative pollution field measurements on outdoor insulators of different material and design", Engineering, Technology \& Applied Science Research, Vol. 5, No. 2, pp. 764-774, 2015

[2] M. A. Eltawil, Z. Zhao, "Grid-connected photovoltaic power systems: Technical and potential problems-a review", Renewable Sustainable Energy Review, Vol. 14, No. 1, pp. 112-129, 2010

[3] A. Kargarnejad, M. Taherbaneh, A. H. Kashefi, "A New Fuzzy-Based Maximum Power Point Tracker for a Solar Panel Based on Datasheet Values", International Journal of Photoenergy, Vol. 2013, Article ID 960510,2013

[4] J. A. R. Hernanz, J. J. C. Martin, I. Z. Belver, J. L. Lesaka, E. Z. Guerrero, E. P. Perez, "Modeling of photovoltaic module", International Conference on Renewable Energies and Power Quality, Granada, Spain, March 23-25, 2010

[5] T. Esram, P. L. Chapman, "Comparison of photovoltaic array maximum power point tracking techniques", IEEE Transactions on Energy Conversion,Vol. 22, No. 2, pp. 439-449, 2007

[6] A. M. Kassem, "MPPT control design and performance improvements of a PV generator powered DC motor-pump system based on artificial neural networks", International Journal of Electrical Power Energy System, Vol. 43, No. 1, pp. 90-98, 2012

[7] G. Farivar, B. Asaei, M. A. Rezaei, "A novel analytical solution for the PV-arrays maximum power point tracking problem”, 2010 IEEE International Conference on Power and Energy, Kuala Lumpur, Malaysia, November 29-December 1, 2010

[8] M. A. Ozcelik, A. S. Yilmaz, "Modification of the incremental conductance algorithm in grid connected photovoltaic systems", Revue Roumaine des Sciences Techniques-Serie Electrotechnique et Energetique, Vol. 61, No. 2, pp. 164-168, 2016

[9] A. Al Nabulsi, R. Dhaouadi, "Efficiency optimization of a DSP-based standalone PV system using fuzzy logic and dual-MPPT control", IEEE Transactions on Industrial Informatics, Vol. 8, No. 3, pp. 573-584, 2012

[10] A. Attou, A. Massoum, M. Chadli, "Comparison study of two tracking methods for photovoltaic systems", Revue Roumaine des Sciences
Techniques-Serie Electrotechnique et Energetique, Vol. 60, No. 2, pp. 205-214, 2015

[11] M. A. G. de Brito, L. Galotto, L. P. Sampaio, G. de A. e Melo, C. A. Canesin, "Evaluation of the Main MPPT Techniques for Photovoltaic Applications", IEEE Transactions on Industrial Electronics, Vol. 60, No. 3, pp. 1156-1167, 2013

[12] H. Patel, V. Agarwal, "MATLAB based modelling to study the effects of partial shading on PV array characteristics", IEEE Transactions on Energy Conversion, Vol. 23, No. 1, pp. 302-310, 2008

[13] H. Kawamura, K. Naka, N. Yonekura, S. Yamanaka, H. Kawamura, H. Ohno, K. Naito, "Simulation of I/V characteristics of a PV module with shaded PV cells", Solar Energy Materials and Solar Cells, Vol. 75, No. 3-4, 75, pp. 613-621, 2003

[14] J. N. Ross, T. Markvart, W. He, "Modeling battery-charge regulation for a stand-alone photovoltaic system", Solar Energy, Vol. 69, pp. 181-190, 2000

[15] A. D. Hansen, P. Sorensen, L. H. Hansen, H. Binder, Models for a Stand-Alone PV System, DTU Library, 2000

[16] L. Castaner, S. Silvestre, Modeling Photovoltaic Systems Using PSpice, John Willy \& Sons, 2002

[17] E. Koutroulis, K. Kalaitzakis, "Development of an integrated dataacquisition system for renewable energy systems monitoring", Renewable Energy, Vol. 28, pp. 139-152, 2003 